\title{
Field Testing Bacterial Wilt-resistant Tomato Somaclones
}

\author{
Carol A. Bobisud, Susan P. Martin, and Terry T. Sekioka \\ Department of Horticulture, Kauai Research Station, University of Hawaii, 7370-A Kuamoo Road, \\ Kapaa, HI 96746
}

Additional index words. somaclonal variation, mutation, Lycopersicon esculentum, Pseudomonas solanacearum

\begin{abstract}
Healani' tomato (Lycopersicon esculentum Mill.) somaclones were tested in a bacterial wilt (Pseudomonas solanacearum E.F. Smith) infected field. Survival percentages of selected somaclonal lines were from $40 \%$ to $100 \%$, while the original 'Healani' had a survival rate of $0 \%$ and resistant 'Kewalo' had $30 \%$. Eighteen bacterial wilt resistant somaclonal lines were selected and tested for retention of horticultural characters in a noninfected field. 'Healani' significantly outyielded all tested somaclonal lines in total fruit weight and total number of fruit per plant. 'Healani' had greater fruit diameter than seven of the lines, greater width of the outer wall of the fruit pericarp than seventeen of the lines, and fewer locules in the fruit than seven of the lines.
\end{abstract}

Somaclonal variation, arising from tissue culture, was initially reported as useful for crop improvement (Larkin and Scowcroft, 1981; Orton, 1984; Scowcroft et al., 1983; Scowcroft and Larkin, 1988; van den Bulk et al., 1990). It has been reported that single gene mutations occur in tomato plants regenerated from callus culture (Evans and Sharp, 1983). The occurrence of classical point mutations has been concluded from genetic analysis of other crops such as rice, wheat, maize, lettuce, tobacco, celery and rapeseed (Scowcroft and Larkin, 1988). Thus, a proposed strategy has been to culture the best cultivars in vitro and select for improvements in the desired character in the regenerants while retaining favorable characters (Evans et al., 1984). Generation of disease resistance through somaclonal variation has been proposed (Skirvin, 1978; van den Bulk et al., 1991). Since there is a dearth of bacterial wilt resistant tomato cultivars, somaclonal variation is a possible method for generating resistance. Thus, it was the purpose of this study to obtain bacterial wilt (Pseudomonas solanacearum) resistance in 'Healani', a susceptible Hawaiian tomato cultivar, through somaclonal variation with the retention of favorable horticultural characters.

\section{Materials and Methods}

Tissue culture. 'Healani' tomato seeds were germinated on sterile, wet filter paper in flasks and placed under fluorescent lights at about $41 \mu \mathrm{mol} \cdot \mathrm{m}^{-2} \cdot \mathrm{s}^{-1}$ in a $25 \mathrm{C}$ culture room at a 12 -h photoperiod. Hypocotyl or cotyledon sections of these seedlings were cultured on modified Murashige and Skoog (MS) media (Murashige and Skoog, 1962) containing concentrations of 2.5/10, 5/10 and $10 / 10 \mu \mathrm{M}$ indole-3-acetic acid (IAA)/ $\mu_{\mathrm{M}}$ 6-benzyladenine (BA). These sections produced calli when grown under the same conditions as the flasks of germinated seedlings. When shoots began to appear from the calli, they were separated and removed from the flask. Rooted shoots were transferred directly into pots in the greenhouse, while the unrooted shoots were placed on MS media with 5 or $10 \mu_{\mathrm{M}} \mathrm{IAA}$ to promote rooting. The remaining calli were transferred to medium with $0 / 2,2.5 / 10$ or $0 / 0\left(\mu_{\mathrm{M}} \mathrm{IAA} / \mu_{\mathrm{M}}\right.$

Received for publication 18 June 1995. Accepted for publication 30 Nov. 1995. Hawaii Institute of Tropical Agriculture and Human Resources journal series no. 4118. The cost of publishing this paper was defrayed in part by the payment of page charges. Under postal regulations, this paper therefore must be hereby marked advertisement solely to indicate this fact.
BA) for further shoot growth. The number of transfers varied, and the period of culture ranged from 3 to 6 months.

Greenhouse and field. Seeds from the self-pollinating regenerants growing in the greenhouse were collected for progeny evaluation.

Table 1. Survival percentages of 'Healani', 'Kewalo', and the $\mathrm{R}_{2}$ progeny of the $\mathrm{R}_{0}$ somaclonal lines tested in the bacterial wilt (Pseudomonas solanacearum) field.

\begin{tabular}{|c|c|c|}
\hline Cultivar or $\mathrm{R}_{0}$ line & No. of plants & Survival percentage \\
\hline$\overline{\mathrm{H} 070101 \mathrm{C}}$ & 15 & $87^{2}$ \\
\hline H070301 & 15 & $47^{2}$ \\
\hline H070301A & 15 & $93^{\mathrm{z}}$ \\
\hline H071002 & 15 & $73^{\mathrm{z}}$ \\
\hline H071002A & 15 & $53^{\mathrm{z}}$ \\
\hline $\mathrm{H} 071002 \mathrm{C}$ & 14 & $43^{z}$ \\
\hline H071003 & 15 & $60^{2}$ \\
\hline H071004 & 15 & $40^{2}$ \\
\hline H071005 & 15 & $40^{z}$ \\
\hline H071006 & 15 & 20 \\
\hline H071009 & 15 & $53^{\mathrm{z}}$ \\
\hline H071009A & 15 & $53^{z}$ \\
\hline H071011 & 15 & 27 \\
\hline H071011A & 15 & 27 \\
\hline H071012A & 15 & $60^{z}$ \\
\hline Н071014 & 15 & 33 \\
\hline H082701 & 15 & 33 \\
\hline H082701A & 15 & $67^{2}$ \\
\hline H082703 & 15 & 40 \\
\hline H082703A & 15 & 33 \\
\hline H082703B & 15 & $47^{2}$ \\
\hline H082710 & 15 & $80^{z}$ \\
\hline H082712 & 15 & 40 \\
\hline H090801 & 11 & $100^{2}$ \\
\hline H090803 & 15 & $53^{\mathrm{z}}$ \\
\hline H090803A & 15 & 20 \\
\hline H090803B & 15 & 33 \\
\hline H102713 OP & 11 & $91^{\mathrm{z}}$ \\
\hline Kewalo & 27 & 30 \\
\hline Healani & 30 & 0 \\
\hline
\end{tabular}

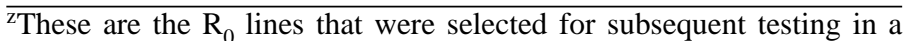
noninfected field. 
Initially, $\mathrm{R}_{1}$ seeds from 41 'Healani' somaclone $\mathrm{R}_{0}$ plants were transplanted into a bacterial wilt infected field in a randomized complete-block design with two replications. (Each $\mathrm{R}_{0}$ plant is an original regenerant; $R_{0}$ breeding lines descend from one plant. $R_{1} s$, $R_{2} s, R_{3} s$, etc. indicate the progeny generation.) There were five plants per $\mathrm{R}_{0}$ line per replication. Only those plants that survived to maturity were labeled resistant. While no cutting of the stems was done to inspect pith browning, resistance was assumed to be differing levels of tolerance (and by no means immunity). Seeds were collected from those $\mathrm{R}_{1}$ plants surviving to maturity for the next trial.

'Kewalo', a cultivar resistant to bacterial wilt disease (Gilbert et al., 1974), was tested along with 'Healani' (susceptible to bacterial wilt) and the $R_{2}$ seeds from 28 of the surviving $R_{0}$ lines in the bacterial wilt infected field in the following year. The design was a randomized complete block with three replications of five plants in each replicate. $R_{3}$ seeds were collected from the surviving plants.

Eighteen $\mathrm{R}_{0}$ lines were selected as bacterial wilt resistant based on a minimum survival rate of $40 \%$. $\mathrm{R}_{3}$ seedlings were planted in a noninfected field along with 'Healani' and 'Anahu' cultivars to evaluate phenotypic characters. The statistical design was a randomized complete block with three replicates and ten plants in each replicate.

Height of the first flower was measured. Plant vigor was rated on a scale of 1 to 5 about 2 months after the seedlings were transplanted into the field. Yield data were the average number and weight of fruit per plant. A sampling of Hawaii no. 1 grade of fruit was taken, usually five per replicate per $\mathrm{R}_{0}$ line or cultivar. Data were taken on fruit diameter, width of the outer wall of the fruit pericarp, number of locules in the fruit, fruit firmness (rating scale of 1 to 5), and percentages of fruit with radial cracks, concentric cracks or hollowness.
Slide preparation for chromosome counts. Root tips from $\mathrm{R}_{3}$ plants were collected from tomato cuttings held in water. Root tips were initially put in a vial of 0.002 м 8-hydroxyquinoline solution for 4 hours in cold water in a thermos, and then fixed with a 1:1:2 solution of $95 \%$ ethanol, chloroform and glacial acetic acid. Root tips were then hydrolyzed with $1 \mathrm{~N}$ hydrochloric acid for $2.5 \mathrm{~min}$ under running hot tap water, and then stored in $45 \%$ acetic acid. Root squashes were stained with aceto-orcein. Extensive chromosome counts of plants grown from seed of the same $\mathrm{R}_{3}$ generation could not be pursued since difficulties arose in obtaining suitable roots and later, nonviable seeds precluded any further work.

\section{Results}

$\mathrm{R}_{2}$ progeny of the lines planted in the bacterial wilt infected field showed survival rates ranging from $20 \%$ to $100 \%$ (Table 1). Degree of resistance for a cultivar may vary from location to location, according to field and environmental conditions. Cultivars 'Healani' (susceptible) and 'Kewalo' (resistant) had survival rates of $0 \%$ and $30 \%$, respectively. Hence, somaclonal bacterial wilt resistance greater than that of 'Kewalo' (under our conditions) was obtained in some lines. These $\mathrm{R}_{2}$ progeny having at least $40 \%$ to $100 \%$ surviving plants in the infected field were selected for further testing.

In the subsequent testing of the $\mathrm{R}_{3}$ progeny of the $\mathrm{R}_{0}$ lines in a noninfected field, mean vigor ratings ranged from 2.7 to 3.6 (scale of $1=$ dead to $5=$ excellent vigor) for all $R_{0}$ lines while the mean ratings of 'Healani' and 'Anahu' were significantly higher at 4.7 and 4.9, respectively (Table 3). 'Healani' differed statistically from only two other lines (H090801 and H090803) in height of the first flower (Table 2).

'Healani' significantly outyielded the $\mathrm{R}_{0}$ lines in total fruit weight per plant and total number of fruit per plant (Table 2). Few

Table 2. Mean values for the characters of height of the first flower, fruit weight per plant, number of fruit per plant, fruit diameter, width of the outer wall of the pericarp of the fruit, and the number of locules per fruit of 'Healani', 'Anahu', and the $\mathrm{R}_{3}$ progeny of the somaclonal lines.

\begin{tabular}{|c|c|c|c|c|c|c|}
\hline $\begin{array}{l}\text { Line or } \\
\text { cultivar }\end{array}$ & $\begin{array}{l}\text { Ht of first } \\
\text { flower } \\
\text { (cm) }\end{array}$ & $\begin{array}{l}\text { Fruit wt } \\
\text { per plant } \\
\quad(\mathrm{kg})\end{array}$ & $\begin{array}{l}\text { Fruit per } \\
\text { plant } \\
\text { (no.) }\end{array}$ & $\begin{array}{l}\text { Fruit } \\
\text { diam } \\
(\mathrm{cm})\end{array}$ & $\begin{array}{l}\text { Width of } \\
\text { outer wall of } \\
\text { fruit pericarp } \\
(\mathrm{cm})\end{array}$ & $\begin{array}{l}\text { Locules } \\
\text { in fruit } \\
\text { (no.) }\end{array}$ \\
\hline$\overline{\mathrm{H} 102713}$ & $25.4 \mathrm{~cd}^{\mathrm{Z}}$ & $1.83 \mathrm{~d}$ & $23.2 \mathrm{~d}$ & $6.05 \mathrm{~cd}$ & $0.44 \mathrm{bc}$ & $8.7 \mathrm{~cd}$ \\
\hline H070101C & $28.2 \mathrm{bcd}$ & $3.27 \mathrm{~cd}$ & $36.3 \mathrm{bcd}$ & $6.66 \mathrm{abc}$ & $0.47 \mathrm{bc}$ & $9.6 \mathrm{bcd}$ \\
\hline H070301 & $26.1 \mathrm{bcd}$ & $3.55 \mathrm{bcd}$ & $38.9 \mathrm{bcd}$ & $6.88 \mathrm{ab}$ & $0.47 \mathrm{bc}$ & $9.3 \mathrm{bcd}$ \\
\hline H070301A & $26.7 \mathrm{bcd}$ & $4.03 \mathrm{bc}$ & $42.8 \mathrm{bc}$ & $6.51 \mathrm{abcd}$ & $0.44 b c$ & $9.5 \mathrm{bcd}$ \\
\hline H071002 & $26.8 \mathrm{bcd}$ & $3.36 \mathrm{bcd}$ & $34.5 \mathrm{bcd}$ & $6.49 \mathrm{abcd}$ & $0.42 \mathrm{c}$ & $14.0 \mathrm{a}$ \\
\hline H071002A & $28.3 \mathrm{bcd}$ & $3.27 \mathrm{~cd}$ & $36.4 \mathrm{bcd}$ & $6.25 \mathrm{bcd}$ & $0.45 \mathrm{bc}$ & $10.3 \mathrm{bc}$ \\
\hline H071002C & $27.2 \mathrm{bcd}$ & $2.76 \mathrm{~cd}$ & $31.9 \mathrm{bcd}$ & $6.14 \mathrm{~cd}$ & $0.43 \mathrm{c}$ & $8.8 \mathrm{bcd}$ \\
\hline H071003 & $29.4 \mathrm{abc}$ & $3.56 \mathrm{bcd}$ & $36.9 \mathrm{bcd}$ & $6.68 \mathrm{abc}$ & $0.51 \mathrm{ab}$ & $10.4 \mathrm{bc}$ \\
\hline H071004 & $28.1 \mathrm{bcd}$ & $4.31 \mathrm{bc}$ & $49.7 \mathrm{~b}$ & $6.54 \mathrm{abcd}$ & $0.45 b c$ & $8.4 \mathrm{~cd}$ \\
\hline H071005 & $29.7 \mathrm{ab}$ & $3.90 \mathrm{bc}$ & $40.2 \mathrm{bcd}$ & $6.61 \mathrm{abc}$ & $0.46 b c$ & $9.7 \mathrm{bcd}$ \\
\hline H071009 & $26.6 \mathrm{bcd}$ & $3.14 \mathrm{~cd}$ & $36.6 \mathrm{bcd}$ & $6.46 \mathrm{abcd}$ & $0.42 \mathrm{c}$ & $9.6 \mathrm{bcd}$ \\
\hline H071009A & $26.9 \mathrm{bcd}$ & $3.53 \mathrm{bcd}$ & $38.7 \mathrm{bcd}$ & $6.57 \mathrm{abcd}$ & $0.39 \mathrm{c}$ & $12.1 \mathrm{ab}$ \\
\hline H071012A & 28.6 abcd & $4.05 \mathrm{bc}$ & $46.9 \mathrm{~b}$ & $6.11 \mathrm{~cd}$ & $0.45 \mathrm{bc}$ & $10.4 \mathrm{bc}$ \\
\hline H082701A & $27.2 \mathrm{bcd}$ & $2.90 \mathrm{~cd}$ & $32.3 \mathrm{bcd}$ & $6.28 \mathrm{bcd}$ & $0.43 \mathrm{c}$ & $9.9 \mathrm{bcd}$ \\
\hline H082703B & $29.5 \mathrm{abc}$ & $3.31 \mathrm{bcd}$ & $34.2 \mathrm{bcd}$ & $6.57 \mathrm{abcd}$ & $0.45 \mathrm{bc}$ & $11.5 \mathrm{abc}$ \\
\hline H082710 & $27.1 \mathrm{bcd}$ & $2.08 \mathrm{~d}$ & $25.6 \mathrm{~cd}$ & $5.90 \mathrm{~d}$ & $0.43 \mathrm{c}$ & $8.5 \mathrm{~cd}$ \\
\hline H090801 & $24.7 \mathrm{~d}$ & $3.04 \mathrm{~cd}$ & $35.9 \mathrm{bcd}$ & $6.17 \mathrm{~cd}$ & $0.46 \mathrm{bc}$ & $8.5 \mathrm{~cd}$ \\
\hline H090803 & $24.2 \mathrm{~d}$ & $3.03 \mathrm{~cd}$ & $33.9 \mathrm{bcd}$ & $6.39 \mathrm{abcd}$ & $0.40 \mathrm{c}$ & $10.8 \mathrm{bc}$ \\
\hline Healani & $29.5 \mathrm{abc}$ & $6.48 \mathrm{a}$ & $69.1 \mathrm{a}$ & $7.04 \mathrm{a}$ & $0.54 \mathrm{a}$ & $6.9 \mathrm{~d}$ \\
\hline Anahu & $32.4 \mathrm{a}$ & $5.05 \mathrm{ab}$ & $43.5 \mathrm{bc}$ & $7.07 \mathrm{a}$ & $0.47 \mathrm{bc}$ & $9.4 \mathrm{bcd}$ \\
\hline
\end{tabular}

${ }^{\mathrm{z}}$ Mean separation in columns by Duncan's multiple range test, $P=0.05$. 
differences in yield occurred among the $\mathrm{R}_{0}$ lines.

'Healani' and 'Anahu' were significantly greater in fruit diameter than seven of the $18 \mathrm{R}_{0}$ lines (Table 2). The width of the outer pericarp wall was significantly greater in 'Healani' than in 17 of the lines. 'Healani' had the least number of locules in the fruit and significantly fewer than seven of the lines. H071002 had the greatest number of locules. There was a lack of radial symmetry in fruit with many locules. In such fruit there were many small locules throughout the fruit with more pericarp tissue observed between the locules.

No significant differences among all $\mathrm{R}_{0}$ lines and cultivars were found for percentages of fruit with concentric cracks or radial cracks (Table 3). Significant differences in percentages of fruit with hollowness (empty cavities within the fruit) were obtained ( $P$ $<0.01$ ) for all lines and cultivars; however, Duncan's multiple range test revealed that 'Healani' yet did not differ significantly from all $\mathrm{R}_{0}$ lines. Lines H070301 and H071004 had 0\% hollowness and were significantly lower than nine of the other lines.

On a scale from 1 (firm) to 5 (soft), 'Healani' fruit had a mean rating of 2.3 for firmness, but did not differ from the $\mathrm{R}_{0}$ lines which ranged in ratings from 1.7 to 2.5 (Table 3 ).

Table 4 indicates that the normal diploid number, $2 n=24$, was generally predominant in the tomato somaclones. Variants from this number were aneuploids and tetraploids. Hence, a mixoploid or mosaic nature in the root tips was apparent.

\section{Discussion}

This study produced plants of 'Healani' that were bacterial wilt resistant. Survival percentages were from $40 \%$ to $100 \%$, which was higher than a $30 \%$ survival rate of resistant 'Kewalo'. Other characters of the somaclonal lines (yield, diameter of fruit, width of the outer pericarp, and locule number) were statistically different from those of the parent cultivar 'Healani'. No significant differences from 'Healani' were found for the percentages of fruit with radial cracks, concentric cracks and hollowness. Yield reduction was a major constraint of this somaclonal variation. Reduced yield has also been observed in somaclones of wheat (Ahloowalia and Sherington, 1985; Qureshi et al., 1992). Inferior fruit were characteristic of many of the tomato somaclonal lines (smaller fruit and abnormalities in radial symmetry accompanied by a higher number of locules dispersed throughout the fruit).

As in wheat (Larkin et al., 1984), different morphological traits in 'Healani' somaclones varied from the original cultivar; however, not all characters changed. Regardless of being polygenically controlled or simply inherited, characters are not always altered in somaclonal variation (Karp and Bright, 1985). In contrast with our results, Daub and Jenns (1989) found progeny of tobacco somaclones to be of a normal phenotype, similar to parental types in yield and leaf chemistry, but resistant in varying degrees to black shank and bacterial wilt.

Limitations of the use of somaclonal variation for bacterial wilt resistance were apparent in 'Healani' tomato due to the accompanying changes. The limited use of somaclonal variation for crop improvement has been noted (Ahloowalia, 1986; van Harten, 1989; Baillie et al., 1992). Somaclonal variation is cultivar dependent (Karp, 1991). While single gene mutations through tissue culture have been reported in tomato (Evans et al., 1984), probabilities are such that several mutations are likely though not always recognized. While Nambisan et al. (1992) observed no variation at the phenotypic level for 950 somaclones of tomato, yet 2 of the 17 somaclones tested showed DNA polymorphism for the $\mathrm{Cab}$ locus. The question still arises whether too many characters are altered in somaclonal variation to be useful in crop improve-

Table 3. Mean values of the characters of plant vigor, fruit firmness, percent radial cracks, percent concentric cracks, and percent hollowness in 'Healani', 'Anahu', and the $\mathrm{R}_{3}$ progeny of the somaclonal lines.

\begin{tabular}{|c|c|c|c|c|c|}
\hline $\begin{array}{l}\text { Line or } \\
\text { cultivar }\end{array}$ & $\begin{array}{l}\text { Plant } \\
\text { vigor }^{2}\end{array}$ & $\begin{array}{c}\text { Fruit } \\
\text { firmness }^{\mathrm{y}, \mathrm{x}}\end{array}$ & $\begin{array}{c}\text { Fruit with } \\
\text { radial cracks } \\
(\%)^{\mathrm{x}}\end{array}$ & $\begin{array}{c}\text { Fruit with } \\
\text { concentric cracks } \\
(\%)^{\mathrm{x}}\end{array}$ & $\begin{array}{c}\text { Fruit showing } \\
\text { hollowness } \\
(\%)\end{array}$ \\
\hline$\overline{\mathrm{H} 102713}$ & $2.7 \mathrm{c}^{\mathrm{w}}$ & 2.4 & 21 & 57 & $7 \mathrm{~cd}$ \\
\hline H070101C & $3.4 \mathrm{bc}$ & 2.1 & 47 & 47 & $40 a b c$ \\
\hline H070301 & $3.6 \mathrm{~b}$ & 2.2 & 27 & 33 & $0 \mathrm{~d}$ \\
\hline H070301A & $3.6 \mathrm{~b}$ & 2.4 & 27 & 27 & $40 a b c$ \\
\hline H071002 & $3.3 \mathrm{bc}$ & 2.2 & 38 & 38 & $38 \mathrm{abc}$ \\
\hline H071002A & $3.2 \mathrm{bc}$ & 2.3 & 20 & 40 & $40 \mathrm{abc}$ \\
\hline $\mathrm{H} 071002 \mathrm{C}$ & $3.1 \mathrm{bc}$ & 2.5 & 7 & 50 & $8 \mathrm{~cd}$ \\
\hline H071003 & $3.5 \mathrm{bc}$ & 2.5 & 33 & 44 & $13 \mathrm{bcd}$ \\
\hline H071004 & $3.2 \mathrm{bc}$ & 2.2 & 13 & 33 & $0 \mathrm{~d}$ \\
\hline H071005 & $3.5 \mathrm{bc}$ & 2.3 & 33 & 53 & $33 a b c$ \\
\hline H071009 & $3.6 \mathrm{~b}$ & 2.4 & 29 & 36 & $14 \mathrm{bcd}$ \\
\hline H071009A & $3.3 \mathrm{bc}$ & 2.1 & 13 & 20 & $21 \mathrm{bcd}$ \\
\hline H071012A & $3.5 \mathrm{bc}$ & 1.7 & 33 & 33 & $31 \mathrm{abc}$ \\
\hline H082701A & $3.2 \mathrm{bc}$ & 2.2 & 56 & 33 & $33 a b c$ \\
\hline H082703B & $3.5 \mathrm{bc}$ & 2.1 & 33 & 40 & $47 \mathrm{ab}$ \\
\hline H082710 & $2.9 \mathrm{bc}$ & 2.4 & 31 & 33 & $27 \mathrm{abcd}$ \\
\hline H090801 & $3.4 \mathrm{bc}$ & 1.8 & 40 & 44 & $20 \mathrm{bcd}$ \\
\hline H090803 & $3.5 \mathrm{bc}$ & 2.2 & 21 & 29 & $50 \mathrm{ab}$ \\
\hline Healani & $4.7 \mathrm{a}$ & 2.3 & 0 & 7 & $20 \mathrm{bcd}$ \\
\hline Anahu & $4.9 \mathrm{a}$ & 2.7 & 6 & 7 & $60 \mathrm{a}$ \\
\hline
\end{tabular}

${ }^{\mathrm{z}}$ Rating is $1=$ dead, $2=$ weak, $3=$ moderate growth, $4=$ good vigor, $5=$ excellent vigor.

'Rating is $1=$ firm, $2=$ moderately firm, $3=$ average, $4=$ moderately soft, $5=$ soft.

xANOVA shows no significant differences.

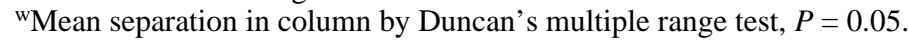


Table 4. Distribution of chromosome numbers found in root tips of $\mathrm{R}_{3}$ plants of 'Healani' tomato.

\begin{tabular}{|c|c|c|c|c|c|c|c|c|c|c|}
\hline \multirow[b]{2}{*}{ Plant } & \multicolumn{10}{|c|}{ Chromosome number distribution } \\
\hline & 21 & 22 & 23 & 24 & 25 & 42 & 43 & 44 & 47 & 48 \\
\hline$\overline{\mathrm{H} 070301 \mathrm{~A} \mathrm{\# 2}}$ & & & & 3 & 2 & & & & 1 & 2 \\
\hline H070301A \#3 & & & 2 & 3 & & & & & & \\
\hline H070301А \#4 & & & 2 & 3 & & & 1 & & 1 & \\
\hline H071005 \#1 & & & & 1 & & & & 1 & & \\
\hline H071005 \#2 & & 1 & & 2 & & & & & & 1 \\
\hline H071005 \#3 & & & 6 & & & & & & & \\
\hline H071005 \#5 & & & 1 & 12 & 1 & & & & & 1 \\
\hline H082701A \#1 & 1 & 2 & & 1 & & 1 & & & & \\
\hline H090803 \#1 & & & & 3 & & & & & & \\
\hline
\end{tabular}

ment (Larkin and Scowcroft, 1983). Therefore, stringent evaluation procedures need to be used (Lorz and Brown, 1986; Larkin and Scowcroft, 1981).

In this study desirable as well as undesirable traits were mutated in the same $\mathrm{R}_{0}$ plants. It is possible to incorporate disease resistance or other desirable characters into 'Healani' with the technique of callus culture. Under our experimental conditions, 'Healani' mutated in several characters along with the trait of bacterial wilt resistance. These mutations generally made the fruit commercially undesirable. Aberrations in chromosome number, mosaicism, have been detected in regenerants of other species or their hybrids (Fedak and Grainger, 1986; Alicchio et al., 1984; Kumar and Walton, 1992; D'Amato et al., 1980) This chromosome mosaicism, in part, may account for the undesirable traits. Crossing to incorporate the bacterial wilt resistance into the original 'Healani' is a possibility; however, the undesirable traits and the chromosome mosaicism may make it too cumbersome and costly to achieve benefits. Traditional breeding with other resistant germplasm may be more desirable for 'Healani'.

\section{Literature Cited}

Ahloowalia, B.S. and J. Sherington. 1985. Transmission of somaclonal variation in wheat. Euphytica 34:525-537.

Ahloowalia, B.S. 1986. Limitations to the use of somaclonal variation in crop improvement, p. 14-27. In: J. Semal (ed.). Somaclonal variations and crop improvement. Martinus Nijhoff, Dordrecht.

Alicchio, R., C. Antonioli, and D. Palenzona. 1984. Karyotypic variability in plants of Solanum melongena regenerated from callus grown in presence of culture filtrate of Verticillium dahliae. Theor. Appl. Genet. 67:267-271.

Baillie, A.M.R., B.G. Rossnagel, and K.K. Kartha. 1992. Field evaluation of barley (Hordeum vulgare L.) genotypes derived from tissue culture. Can. J. Plant Sci. 72:725-733.

D'Amato, F., A. Bennici, P.G. Cionini, S. Baroncelli, and M.C. Lupi. 1980. Nuclear fragmentation followed by mitosis as mechanism for wide chromosome number variation in tissue cultures: Its implications for plant regeneration, p. 67-72. In: F. Sala, B. Parisi, R. Cella, and O. Ciferri (eds.). Plant cell cultures: Results and perspectives. NorthHolland Biomedical Press, Elsevier.

Daub, M.E. and A.E. Jenns. 1989. Field and greenhouse analysis of variation for disease resistance in tobacco somaclones. Phytopathology 79:600-605.

Evans, D.A. and W.R. Sharp. 1983. Single gene mutations in tomato plants regenerated from tissue culture. Science 221:949-951.

Evans, D.A., W.R. Sharp, and H.P. Medina-Filho. 1984. Somaclonal and gametoclonal variation. Amer. J. Bot. 71:759-774.

Fedak, G. and J. Grainger. 1986. Chromosome instability in somaclones of a Triticum crassum $x$ Hordeum vulgare hybrid. Can. J. Genet. and Cytol. 28:618-623.
Gilbert, J.C., J.S. Tanaka, and K.Y. Takeda. 1974. 'Kewalo' tomato. HortScience 9:481-482.

Karp, A. 1991. On the current understanding of somaclonal variation. Oxford Surveys Plant Mol. Cell Biology 7:1-58.

Karp, A. and S.W. J. Bright. 1985. The causes and origins of somaclonal variation. Oxford Surveys Plant Mol. Cell Biol. 2:199-234.

Kumar, P.S. and P.D. Walton. 1992. Plant regeneration and chromosome instability in tissue culture of Elymus canadensis $\times$ E. trachycaulus $\mathrm{F}_{1}$ hybrid. Genome 35:88-91.

Larkin, P.J., S.A. Ryan, R.I.S. Brettell, and W.R. Scowcroft. 1984. Heritable somaclonal variation in wheat. Theor. Appl. Genet. 67:443455.

Larkin, P.J. and W.R. Scowcroft. 1981. Somaclonal variation-A novel source of variability from cell cultures for plant improvement. Theor. Appl. Genet. 60:197-214.

Larkin, P.J. and W.R. Scowcroft. 1983. Somaclonal variation and crop improvement, p. 289-314. In: T. Kosuge, C.P. Meredith, and A. Hollaender (eds.). Genetic engineering of plants: An agricultural perspective. Plenum Press, New York.

Lorz, H. and P.T.H. Brown. 1986. Variability in tissue culture derived plants-Possible origins; advantages and drawbacks, p. 513-534. In: W. Horn, C.J. Jensen, W. Odenbach, and O. Schieder (eds.). Genetic manipulation in plant breeding. Walter de Gruyter, Berlin.

Murashige, T. and F. Skoog. 1962. A revised medium for rapid growth and bioassays with tobacco tissue cultures. Physiol. Plant. 15:473-497.

Nambisan, P., V.L. Chopra, and T. Mohapatra. 1992. DNA polymorphism in $C a b$ locus of tomato induced by tissue culture. Indian J. Expt. Biol. 30:178-180.

Orton, T.J. 1984. Somaclonal variation: theoretical and practical considerations, p. 427-468. In: J. Gustafson (ed.) Gene manipulation in plant improvement. Plenum Press, London.

Qureshi, J.A., P. Hucl, and K.K. Kartha. 1992. Is somaclonal variation a reliable tool for spring wheat improvement? Euphytica 60:221-228.

Scowcroft, W.R. and P.J. Larkin. 1988. Somaclonal variation, p. 21-35. In: Applications of plant cell and tissue culture (Ciba Foundation Symp. 137). Wiley, Chichester.

Scowcroft, W.R., P.J. Larkin, and R.I.S. Brettell. 1983. Genetic variation from tissue culture, p. 139-162. In: J.P. Hegelson and B.J. Deverall (eds.). Use of tissue culture and protoplasts in plant pathology. Academic Press, Sidney.

Skirvin, R.M. 1978. Natural and induced variation in tissue culture. Euphytica 27:241-266.

van den Bulk, R.W., J. Jansen, W.H. Lindhout, and H.J.M. Loffler. 1991. Screening of tomato somaclones for resistance to bacterial canker (Clavibacter michiganensis subsp. michiganensis). Plant Breeding 107:190-196.

van den Bulk, R.W., H.J.M. Loffler, W.H. Lindhout, and M. Koornneef. 1990. Somaclonal variation in tomato: effect of explant source and a comparison with chemical mutagenesis. Theor. Appl. Genet. 80:817825.

van Harten, A.M. 1989. Induced mutations in vegetatively propagated crops, p. 55-91. In: J. Janick (ed.). Plant breeding reviews. vol. 6. Timber Press, Portland, Ore. 